\title{
The Ethics and Factors Influencing Employees Working in the Slovak SME Sector
}

\author{
Tibor Zsigmond, Renáta Machová, Enikő Korcsmáros
}

J. Selye University, Faculty of Economics and Informatics Bratislavská str. 3322, 94501 Komarno, Slovak Republic zsigmondt@ujs.sk,machovar@ujs.sk, korcsmarose@ujs.sk

\begin{abstract}
The roots of the dynamically changing relationship between ethics and entrepreneurship can be found in the past. The ethics of individuals in connection to issues with economic nature had been addressed by Aristotle in ancient Greece. Activities of economic nature and getting wealthy were distinguished. He argued that money cannot serve a purpose to become wealthy, as it is unethical and against the rules of nature. The relationship between ethics and entrepreneurship was first mentioned in the work of Adam Smith (The Wealth of Nations) - "Wise formulation of law has to guarantee that even those who do not possess ethical thinking would act wisely in a fair manner in economic issues". This is the reason why we have developed interest in the relationship of ethics and economy. Herein, we examine 3 hypotheses, formulated as a part of our research, based on 581 obtained responses. The results show that the size of an enterprise influences the existence of ethical institutions. Furthermore, the ethics of the individual, is also influenced by the qualification, while no "real" relationship was detected between the size of company and unethical behavior. Introduction of a Code of Ethics, is strongly advised for the companies.
\end{abstract}

Keywords: business ethics; corporate ethics; individual ethics

\section{Introduction}

Ethics are present in everyday human relationships and is one of the cornerstones of civilized societies. Ethical considerations are often missing from theories of traditional economics. However, thanks to modern economic trends, ethics now plays a key role in the life of companies, as well as in the field of knowledge management. Unfortunately, to this day, it is still common for some companies to behave unethically in certain practices and even cover them up with untrue statements that are obvious to everyone, but everyone pretends to be unaware of them. In many cases, they proceed in a completely opposite way of the values revealed. Instead of the values defined in theory, what matters is what the superior of the individual asks for. And this can often only be completed in unethical ways. 
Superiors often have expectations of employees that they cannot meet in a timely manner without having to resort to unethical steps. If an individual has moral doubts, he or she may not always report them to his or her superiors, but rather remains morally silent. This includes when an individual needs some knowledge to perform a particular task and accesses that knowledge in an unethical manner. It is also possible for an individual to withhold his or her knowledge from others (e.g., co-workers or superiors) to protect his or her own position. So an employee doesn't necessarily share all of their knowledge in order to remain irreplaceable and not benefit any of their employees. It is important to draw attention to these problems.

Companies should strive to use ethical methods in their day-to-day operations to meet individual, organizational and societal expectations. Legislation and regulations have also evolved due to the growing role of ethics. Companies continue to aim to make the most of the time of their workforce, but there are certain mandatory standards and regulations (for example paid leave, appropriate work environment requirements, safety precautions, etc.) that they are required to comply with. Most of these apply equally to all companies, but there are certain internal regulations and rules that vary from company to company. These are created by organizations to provide security and equal treatment for their employees. These measures create a more positive image of companies, both internally and externally, and can help retain the current workforce and "attract" potential future candidates as well. Through this, they can also acquire new strategic and business partners. All large companies have some level of ethical standards, but the situation is no longer so clear for SMEs. Ethical issues need to be managed carefully by companies, as improper handling of them can lead to ignorance and conflict within the organization.

\section{Theoretical Background}

Corporate Ethics is indicated as a part of Business Ethics in the international scientific literature. Foundation of corporate ethics dates back to the 1980s in the USA. Before the 1980s, the movement called "Corporate Social Responsibility", dealing with social responsibility of enterprises addressed the issue. Later, the questions of business ethics became discussed with the issue of corporate responsibility, and thus both corporate and ethical aspects became important. It was only later that this discipline became popular in Europe, and it slightly differed in content from the American concept. Corporate ethics is addressing the issue of ethics within the company [9] [20] [25].

Szegedi [32] in his work distinguished different business ethics trends, based in what form and quality ethics is present in the company. The groups were created based on the theory of Ulrich [35]. According to this, 4 trends were identified, 
which can be detected in currently operating companies. We would like to present these results below. These trends are ranked according to the importance of ethics, starting with the trend where the role of ethics is the minimum [18] [36].

The first trend is based on the traditional perception of enterprise. This trend can be characterized as the "concept of two worlds" [32]. This trend is promoting the ethics-free economy and enterprise. Based on the utilitarian approach, the pursuit of the interest of individuals results in the common good. The main principle is profit maximization. Companies based on this principle were the target of attack, but those supporting this approach believe that it is a legitimate right and duty of the company to maximize profit. Companies have no other moral responsibility. According to Friedmann [11], maximizing profit is the only social responsibility of the company. This approach might sound brave and selfish, but if we examine in broader context, we might change or opinion. According to an expert, it is the duty of the company management to achieve as much profit as possible. This is how the company can fulfill the expectations of company owners and shareholders. If decision is based solely on social responsibility, shareholders receive lower dividends, employees have lower wage or the end users will pay a higher price for purchased products. This approach can be described as immoral as it does not address ethical questions. In this case "immoral" means ethical neutrality. The representatives of this trend emphasize that the company has to respect certain rules (e.g., law, mandatory regulations). So, this trend is not encouraging the accumulation of unethical profit [1] [7] [8] [12] [21].

The second trend is known as instrumental corporate ethics, where corporate ethics is perceived as a tool. This trend emphasizes that it is beneficiary to act ethically in terms of finances, but the company has to invest to corporate ethics as well. These steps might improve the commitment of employees and the image of company can improve for internal and external stakeholders. It also means longterm success for the company [37]. The experience shows that ethical behavior pays off, so it is not surprising that this trend is popular in companies. This trend is represented by Angyal [2], who compares ethics to performance that can be sold as a product. According to him, being ethical is expensive, the companies can benefit from being ethical in long-run. He differentiated four types of companies (ideal, robbers, saints and stupid). This differentiation is based on ethical (good, bad) and economic (profitable, unprofitable) dimensions. He emphasized that companies have to concentrate on profitability. According to his model, the behavior of companies falling to categories "ideal" and "robbers" is acceptable [3].

The trend of instrumental corporate ethics had been widely criticized. Instrumental corporate ethics cannot be called ethics at all, as profit targets are the priority, while ethical goals are subordinated [40]. This is unacceptable. According to Hrubi [16], in terms of this approach we can perceive ethics as a tool of fulfilling the final goal (maximizing profit). According to Lay [19], this approach can be perceived as a hidden trick, where final goal is the "exploitation" [12] [22] [27] 
The next approach is called corrective corporate ethics, which is associated with the charitable activity of the companies. The trend started in the USA, and emerged as a counter reaction to Friedman's theory [11]. Companies have been a subject to heavy criticism for focusing solely on profit and lacking a sense of social responsibility. As a result of this, most of the companies started to sponsor different cultural, sport, scientific and other activities resp. events. It is important to highlight that even this approach is focusing on maximizing the company profit, but part of the generated profit is generously offered for the mentioned activities/events, so the origin of it is not examined from ethical perspective. Profit maximization should be limited by social responsibility of the company. According to corrective approach, ethical aspects are partly taken into account, which contributed to development of corporate ethics [32]. Goodpaster [13] shares an opinion that the companies should not deny the validity of ethical requirements, but should coordinate them. Priority goal should be the profit maximization, but if any legitimate moral issue arises, the corporate ethics has to be applied. Code of Ethics is a tangible sign of the existing corporate ethics [35]. The management of the company determines the ethical boundaries that limit the pursuit of profit [12] [15] [18] [31] [36].

The fourth approach is the integrative corporate ethics, introduced in Switzerland. The representatives of this trend believe that ethical issues and economic expectations have to be combined. It means that the activities of companies have to be both economically rational and ethical. This trend compared to the listed approaches above takes ethics into account to the greatest extent. Ethics is not only a tool having a corrective function, but a basis on which the company success is built. Organizations are the subject of similar ethical expectations as individuals. Higher profit does not entitle the business to be involved or perform unethical behavior. In terms of integrative corporate ethics, companies are related to different groups they have to respect when making decisions. The organizations have to weigh and calculate with the consequences of their decisions. Communication plays a key role in the process. Contrary to the traditional perception of the company, in this case, we speak about "ethical" company management and ethical company. Based on the theory of Szegedi [32] and Radácsi [28], the Aristotelian approach is part of the integrative trend, as profit and ethics go hand in hand. The trend is based on the concept of Aristotle, according to which prevention and development of virtues is the main goal. The trend can be detected in Hungarian companies as well [28] [39]. According to Szegedi [32], the integrative approach is the most appropriate from the listed trends [4] [24] [30].

Morgan [23] came to conclusion that individuals showing unethical behavior think that those in their environment are even more unethical. This conclusion was supported by further studies [10] [29] [38]. Individuals will recognize what is ethical, aware of the rules, but in the case of critical situation, they will focus on the possible consequences of their actions [5]. Instead of the values set in the 
company, the expectations of superiors become important. If individuals solely focus on achieving the goals set by their superiors, they will sometimes apply unethical methods. According to Csókás [7], the occurrence of unethical actions in micro-enterprises is more frequent than in small and medium-sized companies.

\section{Methods and Methodology}

The main goal of our research was to examine which factors influence the most the ethical behavior of individuals within a company. The issue was addressed from the employee perspective, as employees are the basic pillar of organizational success [14] [17]. We chose questionnaire survey for the data collection. The questionnaire contained 17 - closed and semi-closed - questions, which allowed us to collect nominal and ordinal data. The respondents were chosen from the SME sector, as a significant part of the economy is made up by small and medium-sized enterprises [26]. Our research was conducted in Nitra Region from $5^{\text {th }}$ October 2020 till $29^{\text {th }}$ November 2020 (56 days). Survio makes possible to examine the circumstances of filling in the survey. $33.4 \%$ of the respondents opening the questionnaire link had filled in the questionnaire survey. There was not a single respondent who did not finish filling in the questionnaire, so the respondents had already decided to fill in the questionnaire after opening the link. The average time interval filling in the questionnaire was 10-30 minutes. $71.1 \%$ of the respondents needed this time span to complete the task. We managed to address 5,000 companies based on a Slovak database. We asked these companies to forward our questionnaire to their employees. We wanted to examine the responses of employees, so the responses provided by company leaders are not included in the survey results. Self-employed were not included in the survey as well. When processing the research data, we excluded the questionnaires inappropriately filled in. We processed the data obtained from 581 respondents.

We set the following 3 hypotheses:

H1 The existence of ethical institution depends on the size of the company.

H2 Gender, qualification and age have large impact on ethical behavior of the individual.

H3 The occurrence of unethical workplace behavior depends on the size of the company the individual works for.

We set up null (H0) and alternative (H1) hypotheses in case of each hypothesis we defined. The most frequently applied significance level (95\%) was used to test our hypotheses. Pearson's Chi-square test was used to examine the hypotheses:

$x^{2}=\sum_{\text {total cellis }} \frac{\left(f_{0}-f_{e}\right)^{2}}{f_{e}}$ 
The relationship (1) is primarily based on the comparison of expected $\left(f_{e}\right)$ and observed $\left(\mathrm{f}_{0}\right)$ values.

To express the strength of the relationship, the Cramer V indicator (2) was used in one case. $\mathrm{N}$ refers to size of the sample and $\mathrm{k}$ expresses the number of categories:

$V=\sqrt{\frac{\chi^{2}}{N(k-1)}}$

In another case the Goodman and Kruskal's Gamma Coefficient was used (3), where $\mathrm{N}_{\mathrm{c}}$ is the total number of concordant pairs (which rank the same) and $\mathrm{N}_{\mathrm{d}}$ is the number of discordant pairs (which don't rank the same):

$\gamma=\frac{N_{c}-N_{d}}{N_{c}+N_{d}}$

The gamma coefficient ranges between -1 and 1 . (1 means a perfect positive, and 1 a perfect inverse correlation, while 0 means no association at all).

\section{Results}

Regarding the age of our respondents, the categories were set on the basis of scientific work of Berkup (2014). We made some modifications compared to original theory, as we wanted our questionnaire survey to be completed by individuals over the age 18 .

Table 1

Demographic characteristics of respondents

\begin{tabular}{|c|c|c|c|}
\hline \multicolumn{2}{|l|}{ Gender } & \multicolumn{2}{|c|}{ Type of employment } \\
\hline Male & $46.8 \%$ & Part time & $15.8 \%$ \\
\hline Female & $53.2 \%$ & Full time & $84.2 \%$ \\
\hline \multicolumn{2}{|c|}{ Age group } & \multicolumn{2}{|c|}{ Length of employment } \\
\hline 1946-1964 & $4.0 \%$ & Less than a year & $16.9 \%$ \\
\hline $1965-1979$ & $21.3 \%$ & $1-4$ years & $46.3 \%$ \\
\hline 1980-1994 & $44.8 \%$ & $5-10$ years & $19.3 \%$ \\
\hline $1995-2002$ & $29.9 \%$ & $11-30$ years & $16.2 \%$ \\
\hline \multicolumn{2}{|c|}{ Qualification } & More than 30 years & $1.4 \%$ \\
\hline Secondary & $53.5 \%$ & \multicolumn{2}{|c|}{ Net income/month } \\
\hline Tertiary & $46.5 \%$ & Below $500 €$ & $14.5 \%$ \\
\hline \multicolumn{2}{|l|}{ Position } & $501-1000 €$ & $45.1 \%$ \\
\hline Employee & $73.7 \%$ & $1001-1500 €$ & $26.2 \%$ \\
\hline Middle manager & $18.2 \%$ & $1501-2000 €$ & $8.6 \%$ \\
\hline Top manager & $8.1 \%$ & Above $2000 €$ & $5.7 \%$ \\
\hline
\end{tabular}

Source: Own processing 
In order to follow the rule of simplicity, we used only the number of employees to determine the size of the company, as the statistical offices prepare their reports based on the number of employees in the company. Only those micro-enterprises were part of the research, which have at least one employee, who is not selfemployed or the owner of the company. Micro-enterprises are defined as companies employing 1-9 employees. Most of the respondents (49.2\%) work in middle-sized enterprises, followed by the respondents in small enterprises (28.6\%) and finally the micro-enterprises (22.2\%). Most of the companies (26.3\%) work in trade. This was followed by processing industry (12.4\%), tourism and catering (6.4\%), IT and logistics (6.0\%). Despite the relatively large number of sectors listed, an additional $6.2 \%$ of the respondents chose the option "other". The results are presented in Table 1.

\subsection{Main Results}

The first questions asked the respondents whether there are ethical institutions (Code of Ethics, Ethical Committee, training on ethics, etc.) in the organizations they work for. The respondents were offered two basic options ( "yes, there is/yes, there are" or "no, there is not/no, there are not"). 56.5\% of the respondents answered that there are not ethical institutions in their company, while $43.5 \%$ reported that at least one ethical institution is operating in the company. The obtained results will be examined with the help of Hypothesis H1 - taking into account the size of the company.

We asked our respondents whether they think ethical behavior is an advantage. $95.2 \%$ of the respondents think that ethical workplace behavior is a benefit. It is a promising result both for the company and the company leaders, but it would be interesting to examine why $5 \%$ feels that ethical behavior is not a benefit. These employees can cause significant harm to the company.

In the next question, the respondents were asked to indicate on a 5-point Likert scale $(1=$ not at all; $2=$ rather not; $3=$ partly yes, partly no; $4=$ rather yes; $5=$ absolutely) how ethical they think their workplace behavior is. The value of mode is 5 , so the majority of our respondents $(48.5 \%)$ found their workplace behavior ethical. If we also count the option "rather yes" - which is also the median $87.1 \%$ of the respondents behave ethically. The number of respondents selecting options "not at all" (1.9\%) and "rather not" (2.6\%) is relatively low. This is similar to the results we obtained based on the answers to our previous question $4.8 \%$ of the respondents do not find ethical behavior as an advantage. $8.4 \%$ of the respondents reported their behavior "changeable". Overall, we have obtained positive results, however, unethical individuals can cause enormous financial and other type of damage to the company. 
In our next question, we were interested in the opinion of our respondents who they think, a group of individuals or the organizations themselves influence the ethical behavior of the individual. In addition to these, a third option was also proposed, where both of the mentioned factors have influence on the individual. The starting point was that most of the companies have "organizational memory". It can also be manifested in organizational ethics, as individuals can learn from each other. It is valid not only for positive behavior. A new employee can experience unethical workplace behavior from the colleagues. As a reaction, the individual can also make unethical steps in the future. Our results show a high number of respondents $(35.0 \%)$ who think that ethical behavior in the company is solely formed by individuals. However, $19.4 \%$ of the respondents said that ethical behavior of the individual is influenced by the organization. Most of the respondents $(45.6 \%)$ reported that it is a two-way relationship. According to our personal opinion, the organization memory is strongly reflected in ethical behavior. In order to agree with this statement, further research is required. At the same time, it is also important to emphasize the organizational size, as an important influencing factor of the organizational memory. A simple example of this is a micro-enterprise that employs only one person. In this case, we cannot talk about organizational memory, as the replacement of the employee results in cease of organizational memory.

Our next question examined the ethical behavior in details. The question consists of 3 parts. First, we asked the respondents whether it happened that they had behaved unethically in their workplace. $24.3 \%$ of the respondents reported that had happened. $75.5 \%$ of the respondents had never behaved unethically, so they followed ethical rules in their workplace. It is important to highlight that the ratio is far higher than the respondents who found their behavior absolutely ethical (48.5\%). The reason might be that in the previous question the respondents were provided more options, but in this question, they had to choose from two alternatives. A sub-question was also added to this question, where we asked those behaving unethically $(\mathrm{n}=141)$ to indicate what was the reason of their unethical behavior. All of the respondents $(n=581) 8.6 \%$ were afraid of the anger of others. This means $35.5 \%$ of the respondents. $6.2 \%$ of the respondents were afraid of financial damage and $4.5 \%$ were afraid of losing their jobs. In the case of those behaving unethically, the fear of financial damage was $25.5 \%$, while the fear of losing job was $18.4 \%$.

$4.9 \%$ of all respondents (20.6\% of unethical) chose the option "other". This option provided a possibility to respondents to describe the reason of their unethical behavior. Most of the respondents indicated that in majority of cases it was a kind of misunderstanding (1.3\% of unethical), restlessness $(1.2 \%)$ or fatigue $(1.2 \%)$ that resulted in unethical behavior. A further $1.3 \%$ of the respondents indicated a wide diversity of answers that were impossible to categorize.

In our second sub-questions we asked the respondents behaving unethically $(\mathrm{n}=$ 141) to indicate the person they behaved unethically with. The results show that 
mainly the colleagues were the target of unethical behavior $(49.6 \%$ of unethical, $12.0 \%$ of all respondents). The colleagues on the list are followed by superiors/owners $(24.8 \% ; 5.0 \%)$ and buyers/consumers $(20.6 \% ; 5.0 \%)$. Suppliers were ranked the last $(5.0 \% ; 1.2 \%)$. It is not surprising as the least frequent contact is realized with the suppliers. These contacts are mainly impersonal (e-mail, phone). However, we can think that it is easier to behave unethically with those we have less frequent contact with, as the contact is not so strong. In our opinion, the rule of high numbers applies.

We asked the respondents to indicate on a 5-point Likert scale how much they think the ethical culture of the company contributes to the loyalty of individuals. Data collected using the Likert scale were treated as non-metric. The obtained data (frequency) is summarized in the Figure 1 below. In addition to frequency, the mode and median are also presented in connection to single results.

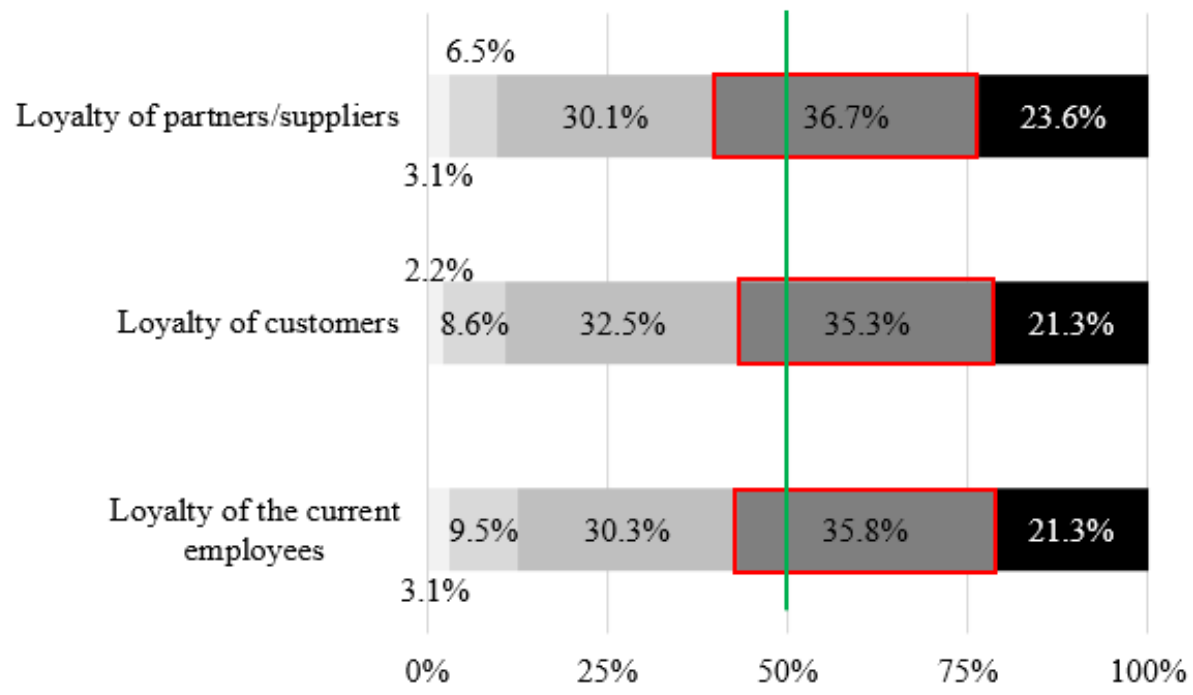

Absulutely not $₫$ Rather not $₫$ Partially yes, partially no $\square$ Rather yes $\square$ Absolutely

- Median $\square$ Mode

Figure 1

Contribution of corporate culture to loyalty - employee perspective

Source: Own processing

The obtained answers don't show significant difference in terms of loyalty among the different groups. If we merge the "absolutely" and "rather yes" options, the loyalty of suppliers/partners $(60.3 \%)$ is the most affected by the company's ethical culture. This is still a negligible significance. Similar result is detected if we merge the categories of "definitely not" and "rather not". The company's ethical culture is the least contributing factor to the loyalty of employees. 


\subsection{Hypotheses Testing}

We formulated 3 hypotheses in our research. It is important to examine whether the existence of ethical institutions is influenced by the company size.

\section{H1: The existence of ethical institutions depends on the size of the company}

Based on the results, the medium-sized companies (57.3\%) put more emphasis on establishing ethical institutions. In the case of small (29.5\%) and micro-enterprises $(31.0 \%)$ we obtained similar results. In order to examine whether or not our results were coincidence, a cross-tabulation analysis was made. Before testing our hypothesis, the following sub-hypotheses were formulated:

Ho There is no relationship between the existence of ethical institutions and the size of the company

H1 There is relationship between the existence of ethical institutions and the size of the company

The size of the company (ordinal) is an independent variable, while the existence of ethical institutions (nominal) is a dependent variable. Chi-square test for crosstabulation analysis was used (Table 2).

Table 2

Cross tabulation - company size and existence of ethical institution(s)

\begin{tabular}{|c|c|c|c|c|c|}
\hline & \multicolumn{2}{|c|}{ Ethical institutions in the company } & \multirow[t]{2}{*}{ Total } \\
\hline & & & $\begin{array}{l}\text { Yes, there are/ } \\
\text { Yes, there is }\end{array}$ & $\begin{array}{l}\text { No, there are not/ } \\
\text { No, there is not }\end{array}$ & \\
\hline \multirow{6}{*}{ 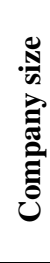 } & \multirow{2}{*}{$\frac{\circ}{\frac{0}{2}}$} & Count & 40 & 89 & 129 \\
\hline & & Exp. Count & 56.2 & 72.8 & 129.0 \\
\hline & \multirow{2}{*}{ 焉 } & Count & 49 & 117 & 166 \\
\hline & & Exp. Count & 72.3 & 93.7 & 166.0 \\
\hline & \multirow{2}{*}{$\frac{\overline{\frac{z}{2}}}{\frac{\pi}{2}} \equiv$} & Count & 164 & 122 & 286 \\
\hline & & Exp. Count & 124.5 & 161.5 & 286.0 \\
\hline \multicolumn{3}{|c|}{ Total } & 253 & 328 & 581 \\
\hline
\end{tabular}

According to the Table 2, the rule of conducting the test is not violated. The values in the Table 3 below can be interpreted as the follows:

Table 3

Chi-square test - company size and existence of ethical institution(s)

\begin{tabular}{|l|l|l|l|}
\hline & Value & df & Asymp. Sig. (2-sided) \\
\hline Pearson Chi-Square & 43.682 & 2 & 0.000 \\
\hline Likelihood Ratio & 44.262 & 2 & 0.000 \\
\hline Linear-by-Linear Association & 33.734 & 1 & 0.000 \\
\hline N of Valid Cases & 581 & & \\
\hline
\end{tabular}


The value of Chi is 43.682. This is much higher than 5.5991 for the selected significance level $(\mathrm{p}=0.05)$ and the degree of freedom (2). So, the obtained result is higher than the critical value of Chi-distribution $\left(\chi^{2}>\chi^{2}\right.$ crit.). The empirical significance level 0.000 is also lower than the significance level determined in our research (0.05). Based on the obtained results, our Hypothesis $\mathrm{H}_{0}$ can be rejectedthere is a relationship between the existence of ethical institutions and the size of the company. As there is significant relationship between, we can examine the strength of this relationship with the help of Cramer V -0.274 , indicating a weak relationship.

Our second hypothesis was formulated as the follows:

\section{H2: Gender, qualification and age have large impact on ethical behavior of the individual}

We wanted to know to what extent gender, qualification and age can influence the level of ethical behavior. We analyzed our hypothesis by dividing it into three parts. First, we measured the relationship between the gender and ethical behavior. The ethical behavior was measured by using a 5-point Likert scale (ordinal). There is a higher percentage of female respondents who find their workplace behavior ethical. If we merge the categories of "rather yes" and "absolutely", $87.4 \%$ of the female respondents and $86.7 \%$ of male respondents declared to behave ethically in their workplace. In order to examine whether these results are due to coincidence or not, we prepared a cross-tab. Before testing, the following sub-hypotheses were formulated:

$\mathbf{H}_{0}$ There is no relationship between gender and ethical behavior

H1 There is relationship between gender and ethical behavior

The independent variable - gender - was measured using a nominal (non-metric) variable consisting of two categories. A cross-tab (Table 4) was prepared for analysis.

Table 4

Cross-tab with observed and expected results - gender and ethical behavior

\begin{tabular}{|c|c|c|c|c|c|c|c|c|}
\hline & \multicolumn{5}{|c|}{ How ethical you find your own behavior? } & \multirow[b]{2}{*}{ Total } \\
\hline & & & $\begin{array}{l}\text { Absolu- } \\
\text { tely not }\end{array}$ & $\begin{array}{c}\text { Rather } \\
\text { not }\end{array}$ & Partially & $\begin{array}{c}\text { Rather } \\
\text { yes }\end{array}$ & $\begin{array}{c}\text { Absolu- } \\
\text { tely }\end{array}$ & \\
\hline \multirow{4}{*}{ 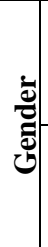 } & \multirow{2}{*}{$\begin{array}{l}\frac{0}{\widetilde{J}} \\
\text { D̃ } \\
\text { I }\end{array}$} & Count & 5 & 9 & 25 & 114 & 156 & 309 \\
\hline & & $\begin{array}{l}\text { Exp. } \\
\text { Count }\end{array}$ & 5.9 & 8.0 & 26.1 & 119.1 & 150.0 & 309.0 \\
\hline & \multirow{2}{*}{$\frac{0}{\sum^{J}}$} & Count & 6 & 6 & 24 & 110 & 126 & 270 \\
\hline & & $\begin{array}{l}\text { Exp. } \\
\text { Count }\end{array}$ & 5.1 & 7.0 & 22.9 & 104.9 & 132.0 & 270.0 \\
\hline \multicolumn{3}{|c|}{ Total } & 11 & 15 & 49 & 224 & 282 & 581 \\
\hline
\end{tabular}

Source: Own processing 
According to the Table 4, the rule of conducting the test is not violated. The values in the Table 5 below can be interpreted as the follows:

Table 5

Chi-square test - gender and ethical behavior

\begin{tabular}{|l|l|l|l|}
\hline & Value & df & Asymp. Sig. (2-sided) \\
\hline Pearson Chi-Square & 1.625 & 4 & 0.804 \\
\hline Likelihood Ratio & 1.627 & 4 & 0.804 \\
\hline Linear-by-Linear Association & 0.524 & 1 & 0.469 \\
\hline N of Valid Cases & 581 & & Source: Own processing \\
\hline
\end{tabular}

The value of Chi is 1.625 , which is lower than 9.488 at the significance level $(p=0.05)$ and the degree of freedom 4 . The value obtained is lower than the critical value of the Chi distribution $\left(\chi^{2}<\chi^{2}\right.$ crit.). Furthermore, the value of empirical significance level (0.804) is also higher than the significance level (0.05) determined in our research. Based on the results, hypothesis $\mathrm{H}_{0}$ cannot be rejected, so there is no relationship between the gender and ethical behavior.

As a next step we wanted to examine the relationship between qualification and ethical behavior. If we merge the categories "rather yes" and "absolutely", 92.6\% of the respondents with tertiary degree and $82.4 \%$ of the respondents with secondary degree declared themselves ethical. In order to examine whether these results are due to coincidence or not, we prepared a cross-tab. Before testing, the following sub-hypotheses were formulated:

Ho There is no relationship between the qualification of individuals and their ethical behavior

$\mathbf{H}_{1}$ There is a relationship between the qualification of individuals and their ethical behavior

We tested the independent variable - qualification - with an ordinal (non-metric) variables consisting of 2 categories. A cross-tab (Table 6) was prepared for analysis.

Table 6

Cross-tab with observed and expected results - qualification and ethical behavior

\begin{tabular}{|c|c|c|c|c|c|c|c|c|}
\hline \multirow{2}{*}{\multicolumn{3}{|c|}{ S }} & \multicolumn{5}{|c|}{ How ethical you find your own behavior? } & \multirow[b]{2}{*}{ Total } \\
\hline & & & $\begin{array}{c}\text { Absolutely } \\
\text { not }\end{array}$ & $\begin{array}{c}\text { Rather } \\
\text { not }\end{array}$ & Partially & $\begin{array}{c}\text { Rather } \\
\text { yes }\end{array}$ & Absolutely & \\
\hline \multirow{4}{*}{ 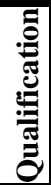 } & \multirow{2}{*}{ 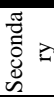 } & Count & 7 & 11 & 37 & 128 & 128 & 311 \\
\hline & & Exp. Count & 5.9 & 8.0 & 26.2 & 119.9 & 151.0 & 311.0 \\
\hline & \multirow{2}{*}{ 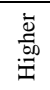 } & Count & 4 & 4 & 12 & 96 & 154 & 270 \\
\hline & & Exp. Count & 5.1 & 7.0 & 22.8 & 104.1 & 131.0 & 270.0 \\
\hline \multicolumn{3}{|c|}{ Total } & 11 & 15 & 49 & 224 & 282 & 581 \\
\hline
\end{tabular}

Source: Own processing 
According to the Table 6, the rule of conducting the test is not violated. The values in the Table 7 below can be interpreted as the follows:

Table 7

Chi-square test - qualification and ethical behavior

\begin{tabular}{|l|l|l|l|}
\hline & Value & df & Asymp. Sig. (2-sided) \\
\hline Pearson Chi-Square & 21.020 & 4 & 0.000 \\
\hline Likelihood Ratio & 21.693 & 4 & 0.000 \\
\hline Linear-by-Linear Association & 16.853 & 1 & 0.000 \\
\hline N of Valid Cases & 581 & & \\
\hline
\end{tabular}

Source: Own processing

The value of Chi was 21.020, which is higher than -9.488 indicated at the significance level $(p=0.05)$ and the degree of freedom 4 . So, the obtained result for test function is higher than the critical value of Chi-distribution $\left(\chi^{2}>\chi^{2}\right.$ crit.). In addition, the empirical level of significance 0.000 is lower than the significance level (0.05) determined in our research. Based on the results, hypothesis $\mathrm{H}_{0}$ can be rejected. There is relationship between the qualification and ethical behavior. Since there is a significant relationship between our 2 ordinal variables, we can examine the strength between them. In the case of ordinal variables, the Gamma index was used for this purpose. The value of Gamma was 0.310. It means that the respondents with higher qualification consider their workplace behavior ethical.

Finally, we wanted to examine the relationship between the age and ethical behavior. The independent variable - age group - was measured with a help of an ordinal variable consisting of four categories. No difference was detected between different age groups. If we merge the categories "rather yes" and "absolutely", the most ethical were the respondents born between 1980 and 1994 (89.6\%). They are followed by those born between 1995 and 2002 with $85.7 \%$, then the respondents born between 1965 and 1979 with $84.7 \%$. The last position is taken by the respondents born between 1945 and 1964 with $82.6 \%$. In order to examine whether these results are due to coincidence or not, we prepared a cross-tab (Table 8). Before testing, the following sub-hypotheses were formulated:

Ho There is no relationship between the age group of the respondents and their ethical behavior

$\mathbf{H}_{1}$ There is a relationship between the age group of the respondents and their ethical behavior

The independent variable - age - was examined with the help of nominal (nonmetric) variable consisting of four categories. The rule of conducting the test had been violated, the expected value was less than 5 . This is the reason why we merged the different levels of being ethical ("absolutely not" ethical and "rather ethical"). 
Table 8

Cross-tab with observed and expected results - age group and ethical behavior - merged

\begin{tabular}{|c|c|c|c|c|c|c|c|}
\hline & & & \multicolumn{4}{|c|}{ How ethical you find your own behavior } & \multirow[b]{2}{*}{ Total } \\
\hline & & & $\begin{array}{c}\text { Absolutely not } \\
+ \text { rather not }\end{array}$ & Partially & $\begin{array}{c}\text { Rather } \\
\text { yes }\end{array}$ & Absolutely & \\
\hline \multirow{8}{*}{ 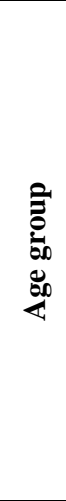 } & \multirow{2}{*}{ 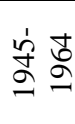 } & Count & 2 & 2 & 9 & 10 & 23 \\
\hline & & $\begin{array}{l}\text { Exp. } \\
\text { Count }\end{array}$ & 1.0 & 1.9 & 8.9 & 11.2 & 23.0 \\
\hline & \multirow{2}{*}{ 它会 } & Count & 7 & 12 & 39 & 66 & 124 \\
\hline & & $\begin{array}{l}\text { Exp. } \\
\text { Count }\end{array}$ & 5.5 & 10.5 & 47.8 & 60.2 & 124.0 \\
\hline & \multirow{2}{*}{ 官 } & Count & 9 & 18 & 103 & 130 & 260 \\
\hline & & $\begin{array}{l}\text { Exp. } \\
\text { Count }\end{array}$ & 11.6 & 21.9 & 100.2 & 126.2 & 260.0 \\
\hline & \multirow{2}{*}{ ڤ่ } & Count & 8 & 17 & 73 & 76 & 174 \\
\hline & & $\begin{array}{l}\text { Exp. } \\
\text { Count }\end{array}$ & 7.8 & 14.7 & 67.1 & 84.5 & 174.0 \\
\hline \multicolumn{3}{|c|}{ Total } & 26 & 49 & 224 & 282 & 581 \\
\hline
\end{tabular}

According to the Table 8, the expected value is less than 5 in 2 cases, but it means only $13.33 \%$, so the rule of conducting the test was not violated. The values in the Table 9 below can be interpreted as the following:

Table 9

Chi-square test - age group and ethical behavior

\begin{tabular}{|l|l|l|l|}
\hline & Value & df & Asymp. Sig. (2-sided) \\
\hline Pearson Chi-Square & 7.065 & 9 & 0.630 \\
\hline Likelihood Ratio & 7.015 & 9 & 0.636 \\
\hline Linear-by-Linear Association & 0.153 & 1 & 0.695 \\
\hline N of Valid Cases & 581 & \multicolumn{2}{|l}{} \\
\hline
\end{tabular}

Source: Own processing

The value of Chi is 7.065, which is lower than 16.919 indicated at a significance level of $(\mathrm{p}=0.05)$ and the degree of independence 9 . So, the value of test function is lower than the Chi-distribution ( $\chi^{2}<\chi^{2}$ crit.). In addition, the level of empirical significance 0.630 is higher than the significance level (0.05) determined for our research. Based on the obtained results, hypothesis $\mathrm{H}_{0}$ cannot be rejected. It means that there is no relationship between the age group the respondents belong to and their ethical behavior. It means that our original hypothesis, $\mathrm{H}_{2}$ "Gender, qualification and age have large impact on ethical behavior of the individual." can partially be accepted and partially rejected. While qualification of individuals has influence on ethical behavior, in terms of gender and age group this influence cannot be detected. 
Hypothesis $\mathrm{H}_{3}$ was formulated as the following:

\section{H3: The occurrence of unethical workplace behavior depends on the size of the company the individual works for.}

We were looking for an answer, whether ethical behavior of the individual can be influenced by the size of the company he/she works for. It was also interesting, whether the employees working for medium-sized companies are more likely to behave unethically than the employees of small and micro-enterprises. Ethical were considered those employees who declared about themselves that they have never behaved unethically in their workplace. In contrast, unethical refers to those respondents who have already taken unethical steps in their workplace. Based on the obtained results, there is no significant difference between different types of companies in terms of ethical behavior. $74.4 \%$ of employees in micro businesses, $77.7 \%$ working in small enterprises and $75.2 \%$ employees in medium-sized enterprises reported to behave ethically in workplace. In order to examine whether these results are due to coincidence or not, we prepared a cross-tab analysis. Before testing, the following sub-hypotheses were formulated:

Ho There is no relationship between unethical behavior and company size

$\mathbf{H}_{1}$ There is relationship between unethical behavior and the company size

The ethical behavior was measured with a help of question the respondents had an option to answer "yes" or "no", so the dependent variable was nominal. The independent variable is an ordinal (non-metric) variable consisting of three categories. A Chi-square test was applied as a part of cross-tab analysis (Table $10)$.

Table 10

Cross-tab with observed and expected results - Hypothesis $H_{3}$

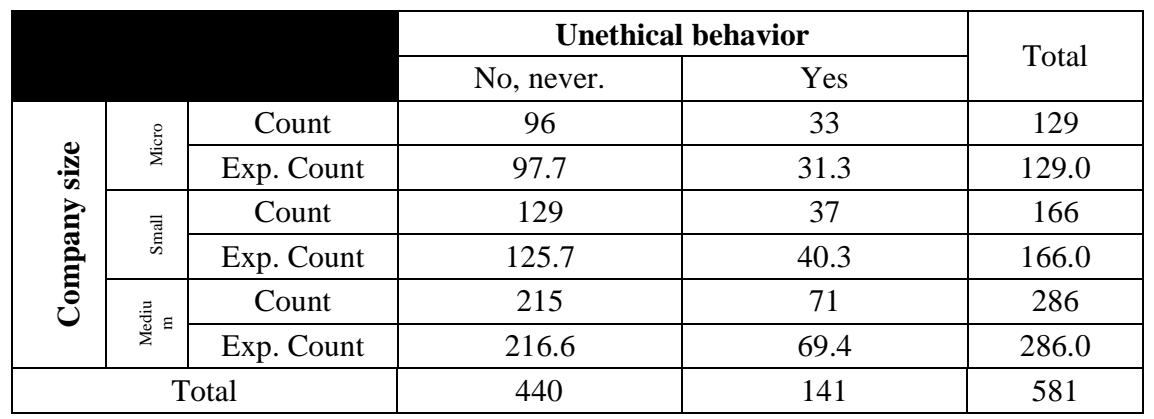

Source: Own processing 
According to the Table 10, the rule of conducting the test is not violated, the value is not less than 5 in each case. The values in the Table 11 below can be interpreted as the following:

Table 11

Results of Chi-square test - Hypothesis $\mathrm{H}_{3}$

\begin{tabular}{|l|l|l|l|}
\hline & Value & df & Asymp. Sig. (2-sided) \\
\hline Pearson Chi-Square & 0.523 & 2 & 0.770 \\
\hline Likelihood Ratio & 0.528 & 2 & 0.768 \\
\hline Linear-by-Linear Association & 0.000 & 1 & 0.990 \\
\hline N of Valid Cases & 581 & & Source: Own processing \\
\hline
\end{tabular}

The value of Chi is extremely low -0.523 . It is lower than 5.991 indicated at determined level of significance $(\mathrm{p}=0.05)$ and the degree of independence 2 . Thus, the value of test function is lower than the critical value of Chi-distribution $(\chi 2<\chi 2$ crit.). The level of empirical significance is 0.770 , which is much higher than the significance level (0.05) determined in our research. Based on the obtained results, the null hypothesis cannot be rejected, which means that there is no relationship between the company size and ethical behavior. It means that the original hypothesis $\mathrm{H}_{3}$ : "The occurrence of unethical behavior depends on the size of the company the individual works for." is rejected.

\section{Conclusions}

The main goal of our research was to examine which factors have the greatest influence on ethical behavior within a company. The companies were approached from the employee's perspective.

In order to test our hypotheses, the results of the employee questionnaire survey were processed. Hypothesis $\mathrm{H}_{1}$ was approved, since there is a relationship between the existence of ethical institutions and the size of the company. Hypothesis $\mathrm{H}_{2}$ was approved partially. According to the results, the qualification influences the ethical behavior, while the gender and age group the respondents belong to has no impact on ethical behavior. The respondents with higher qualification find their workplace behavior ethical. Hypothesis $\mathrm{H}_{3}$ was rejected, since no relationship was found between the company size and the occurrence of unethical behavior. This contradicts the statement of Csókás [7], as unethical behavior shows higher frequency in micro-enterprises. We have to highlight that Csókás asked the respondents whether they have or not experienced unethical behavior in their workplaces. The current research asked the respondents to provide information about their own workplace behavior. This may therefore be related to what we stated before that the employees are unlikely to be critical with their own ethical behavior. 
We had to face certain barriers in our research. These barriers were financial and the lack of time was also an obstacle to our research. We also have to highlight the criticism related to quantitative research methods. Since the respondents had to report about themselves, it could happen that they interpreted the questions from different perspectives. These test results show, how individuals see themselves and their qualities, but it can differ from the reality. It is important to mention the scope of our questionnaire as well. We expected that not many respondents will fill in the questionnaire. Unlike our expectations, we received adequate number of answers.

The introduction of a Code of Ethics is strongly advised for companies, as the incidence of unethical behavior is frequent in the companies and the Code of Ethics is the easiest corporate ethical institution to introduce.

It would be useful to use further research methods in the future; as selfadministered questionnaires do not necessarily, reflect reality. There are no specific scales to measure the ethical behavior, so we had to rely on the responses of employees. These provided the necessary statistical basis for our research. We would like to contact more potential respondents to complete the questionnaire, as well as, use offline opportunities, to obtain more detailed information. We would also like to conduct interviews, to study the opinions of managers and company leaders. We plan to expand our research in national and international scales. Opportunities are also possible by examining the further factors of emotional intelligence [6] and/or artificial intelligence [33] [34].

\section{References}

[1] Ahmed, J. U.; Islam, Q. T.; Ahmed, A., Faroque, A. R.; Uddin, M. J.: Corporate social responsibility in the wake of COVID-19: multiple cases of social responsibility as an organizational value. Society and Business Review, 2021, Vol. 16, No. 4, pp. 496-516

[2] Angyal, Á. Nézetek az erkölcsről: avagy a malaszt természete. (Views on morality: or the nature of malt) Aula Kiadó (Publisher), 2003, p. 268

[3] Bakó, T.: Decision-Making Specialities in the Light of Corporate Social Responsibility. Bulletin of the National Technical University "Kharkiv Polytechnic Institute" (economic Sciences), 2019, No. 1, pp. 40-44

[4] Benedek, A.; Takácsné György, K.: A felelős vállalatirányítás személyi tényezői: A CSR-központ felelős vállalatvezetők attitüdjének vizsgálata a kis- és középvállalatok körében (Examination of attitudes of CSR-center responsible corporate leaders among small and medigum enterprises). Vezetéstudomány - Budapest Management Review (Journal), 2016, Vol. 47, No. 1, pp. 58-67

[5] Berber, N.; Slavic, A.; Miletic, S.; Simonovic, Z.; Aleksic, M.: A Survey on Relationship between Leadership Styles and Leadership Outcomes in the 
Banking Sector in Serbia. Acta Polytechnica Hungarica, 2019, Vol. 16, No. 7, pp. 167-184

[6] Cabral, A. M. R.; De Oliveira Carvalho, F. M. P.: Emotional Intelligence and Ethics on Organizations. Open Journal of Business and Management, 2014, Vol. 2, No. 1, pp. 5-23

[7] Csókás, L.: Leadership versus etika: illúzió vagy valóság? (Leadership versus ethics: illusion or reality?) Doctoral dissertation, J. Selye University, 2017, p. 127

[8] Czarneczka, A.; Albrychiewicz-Slocinska, A.; Paven, I. G.; Poor, J.; Skiba, L.: Utilitarian ethical attitudes towards young employees. Managerial Trends in the Development of Enterprises in Globalization Era, 2017, pp. 321-327

[9] Duh, M.; Belak, J.: The Influence of a Family on Ethical Behaviour of a Family Enterprise. Acta Polytechnica Hungarica, 2009, Vol. 6, No. 3, pp. $35-56$

[10] Flanagan, J.: Philosophical methodology and leadership ethics. Leadership, 2018, Vol. 14, No. 6, pp. 707-730

[11] Friedman, M.: The Social responsibility of Business Is to Increase Its Profits. The New York Time Magazine, 1970, No. 13, pp. 122-126

[12] Garcia-Alcaraz, J. L.; Flor-Motalvo, F. J.; Avelar-Sosa, L.; SanchezRamirez, C.; Jimeez-Macias, E.: Human Resource Abilities and Skills in TQM for Sustainable Enterprises. Sustainability, 2019, Vol. 11, No. 22

[13] Goodpaster, K. E.: Business Ethics. The Blackwell Encyclopedia of Management. Business Ethics. Oxford: Blackwell Publishing, 2006, pp. 5662

[14] Hajduova, Z.; Peracek, T.; Hurajova, J.; Bruothova, M.: Determinants of innovativeness of Slovak SMEs. Problems and Perspectives in Management, 2021, Vol. 19, No. 1, pp. 198-208

[15] Hald, J. E.; Gillespie, A.; Reader, T. W.: Causal and Corrective Organisational Culture: A Systematic Review of Case Studies of Institutional Failure. Journal of Business Ethics, 2020, No. 174, pp. 457483

[16] Hrubi, F. R.: Ethik und Management. Wirtschaftsethik: Aufsatzsammlung (Ethics and management. Business ethics: collection of essays). Suriptenuerlag der Hochschölerschaft der Wirtschaftsoniversitat (Journal), 1993, pp. 78-83

[17] Jaškevičiūte, V.: Trust in organization effect on the relationship between HRM practices and employee well-being. Business and Regional Development 2021, SHS Web of Conferences, 2021, No. 120 
[18] Kirchmayer, Z.; Remisova, A.; Lasakova, A.: The Perception of Ethical Leadership in the Public and Private Sectors in Slovakia. Journal of East European Management Studies, 2019, No. SI, pp. 10-36

[19] Lay, R.: Ethik für Manager (Ethics for managers). ECON Taschenbuch Verlag (Publisher), 1996, p. 252

[20] Löhr, A.: Wirtschaft- und Unternehmensethik in Europa (Economic and business ethics in Europe). Forum Wirtschaftsethik (Journal), 1995, Vol. 3, No. 3, pp. 15-21

[21] Manuel, T.; Herron, T. L.: An ethical perspective of business CSR and the COVID-19 pandemic. Society and Business Review, 2020, Vol. 15, No. 3, pp. $235-353$

[22] Milojevic, I.; Mihajlovic, M.; Popovic, M.; Pantic, N. Application of Quantitative Models in the Organization of the Financial Function of Agricultural Enterprises. Ekonomika Poljoprivreda-Economics of Agriculture, 2020, Vol. 67, No. 3, pp. 747-762

[23] Morgan, R. B.: Self- and Co-Worker Perceptions of Ethics and Their Relationships to Leadership and Salary. Academy of Management Journal, 1993, Vol. 36, No. 1, pp. 200-214

[24] Mura, L.: Základy etiky. (Fundamentals of Ethics) University Script, PanEuropean University, Faculty of Economics and Entrepreneurship, 2017, p. 80

[25] Mura, L.; Machyniak, J.: Ethical Aspects of Public Administration. 12 $2^{\text {th }}$ International Conference on Hradec Economic Days (HED 2014): Economic Development and Management of Regions, 2014, No. V, pp. 5965

[26] Najib, M.; Rahman, A. A. A.; Fahman, F.: Business Survival of Small and Medium-Sized Restaurants through a Crisis: The Role of Government Support and Innovation. Sustainability, 2021, Vol. 13, No. 19

[27] Ortner, H. M.: The human factor in quality management. Accreditation and Quality Assurance, 2000, Vol. 5, No. 4, pp. 130-141

[28] Radácsi, L.: Szervezeti etika és intézményesítés (Corporate ethics and institutionalization). Doctoral dissertation. BKÁE, 2000, p. 137

[29] Shaheer, N.; Yi, Y. T.; Li. S. L.; Chen, L.: State-Owned Enterprises as Bribe Payers: The Role of Institutional Environment. Journal of Business Ethics, 2019, Vol. 159, No. 1, pp. 221-238

[30] Smejs, J.; Binka, B.; Rolný, I.: Etika, ekonomika, prríroda (Etika, ekonomika, př́roda). Grada, 2012, p. 192 
[31] Soltysik, M.; Zakrzewska, M.; Sagan, A.; Jarosz, S.: Assessment of Project Manager's Competence in the Context of Individual Competence Baseline. Education Sciences, 2020, Vol. 10, No. 5

[32] Szegedi, K.: Üzleti etika a gyakorlatban - etikai intézmények (Business ethics in practice - ethical institutions) Nemzeti Tankönyvkiadó (Publisher), 2011, p. 100

[33] Szenes, K.; Tureczki, B.: Interdisciplinary Optimization of Security Operations Centers with Digital Assistant. IEEE $15^{\text {th }}$ International Symposium on Applied Computational Intelligence and Informatics (SACI 2021) 2021, pp. 397-401

[34] Tureczki, B.; Szenes, K.: AI supported Corporate Governance. 19th IEEE World Symposium on Applied Machine Intelligence and Informatics (SAMI 2021), 2021, pp. 465-469

[35] Ulrich, P.: Integrative Wirtschaftsethik: Grundlagen einer lebensdienlichen Ökonomie (Integrative business ethics: Basics of a life-serving economy). Verlag Paul Haupt (Publisher), 2007, p. 558

[36] Remisova, A.; Lasakova, A.; Kirchmayer, Z.: Influence of Formal Ethics Program Components on Managerial Ethical Behavior. Journal of Business Ethics, 2019, Vol. 160, No. 1, pp. 151-166

[37] Romar, E. J.: Strategic Intent, Confucian Harmony and Firm Success. Acta Polytechnica Hungarica, 2009, Vol. 6, No. 3, pp. 57-67

[38] Valentine, S.; Godkin, L.: Ethics policies, perceived social responsibility, and positive work attitude. Irish Journal of Management, 2016, Vol. 35, No. 2, pp. $114-128$

[39] Vrannai, K.: Vállalatok társadalmi felelősségtudata: érdekek és érdemek (Corporate social responsibility: interests and merits) Figyelö (Journal), 2000, Vol. 44, No. 47, pp. 67-70

[40] Ziegler, A.: Unternehmensethik - schöne Worte oder dringende Notwendigkeit? (Business Ethics - Nice Words or Urgent Necessity?) University of St. Gallen, 1987, p. 41 